\title{
Innovation and Export Performance: An Empirical Insight on the Effect of Innovation on Manufacturing Firms in Cameroon
}

\author{
Dobdinga Cletus Fonchamnyo ${ }^{1} \&$ Vukenkeng Andrew Wujung ${ }^{2}$ \\ ${ }^{1}$ Department of Economics, Faculty of Economics and Management Sciences, The University of Bamenda, P.O. Box 39, \\ Bambili, North West Region, Cameroon. \\ ${ }^{2}$ HTTTC, The University of Bamenda, The University of Bamenda, P.O. Box 39, Bambili, North West Region, \\ Cameroon.
}

Correspondence: Dobdinga Cletus Fonchamnyo, Department of Economics, Faculty of Economics and Management Sciences, The University of Bamenda, P.O. Box 39, Bambili, North West Region, Cameroon.

Received: June 23, 2016

doi:10.11114/aef.v3i4.1682
Accepted: July 12, 2016

Available online: August 4, 2016

URL: http://dx.doi.org/10.11114/aef.v3i4.1682

\begin{abstract}
The objective of this paper was to examine the effects of innovation types on the intensity and propensity to export by manufacturing firms in Cameroon. The data were secondary based on statistics collected by the International Development Research Centre (IDRC) on the manufacturing firms in Cameroon between 2011 and 2013. The data were analysed using the tobit and logit estimation techniques. The analyses revealed that different innovation activities namely process, product, market and organisation innovations have been instituted by firms in Cameroon. The empirical results showed that innovation has a positive effect on both the probability and volume to export. Specifically, only non-technological innovations significantly account for variations in export performance, while technological embedded innovations insignificantly influence export variation. Precisely, the results indicated that market and organizational innovations significantly increase intensity and propensity to export, while product innovation has a significant and positive effect on quantity exported and not on export likelihood. Other findings showed that corruption retards export performance while a stable macro-economy improved upon export performance. The findings therefore support government and public policies that promote innovative ways of firms in carrying out their daily activities.
\end{abstract}

Keywords: Innovation, Export Performance, Manufacturing firms, Cameroon

JEL Classification: D2, F14, O31

\section{Introduction}

The role of innovation as a source of growth both at the level of the firm and the economy as a whole has attracted the attention of researchers lately. For instance, Schumpeter (1942) considered innovation to be at the centre of economic activities, while proponents of endogenous growth (Aghion \& Howitt, 1992) considered innovations that deal with the introduction of new techniques to produce new goods as an indispensable condition for long-term growth. This argument has resulted to massive growth in theoretical literature in an attempt to link growth to innovations. Despite this the empirical evidence has fully not been developed partly due to difficulties in defining and measuring innovation (Rogers, 2003). Thus, it is difficult to appreciate the effects of innovation empirically.

Despite the insufficient empirical studies, increasing integration of world economies has led many firms from developing countries to concentrate efforts to exportation as a necessary requirement for their future growth and sustainability (Sousa \& Alserhan, 2002). This is considered the case because exports offer the easiest means to expand and penetrate into the foreign markets compared to other forms of international engagements such as joint ventures and overseas investment (Tesfom \& Litz, 2006). However, the foreign markets are embedded with a lot of uncertainty which necessitates firms to procure export market information and/or intelligence (concerning competitors, customers, prices, technology and government regulations), disseminate and act on the information (Jasmine and William, 2005; Salavou, 2002). This approach to penetrate foreign markets has been referred to as export market orientation (Alhakimi \& Baharun; 2009). Accordingly, Hoq \& Norban (2009) observed that when firms adopt policies aimed at market orientation, it is easier for such firms to gather information that facilitates innovation. Many other studies have also evaluated the market orientation by analysing the competitiveness of the firms and the ways in which they can utilize 
their competitive advantages to gain a larger market share (Riasi, 2015)

Thus, information on innovation is therefore crucial for improving competitiveness and productivity in developing countries that plan to emerge and converge to the per capita income levels similar to those of the richest economies. In this respect, innovation is essential for increasing productivity and sustaining growth for developing countries as a whole. Evidence shows that applying technological advances leads to a more effective use of productive resources and the transformation of new ideas into new economic solutions which is important for sustainable competitive advantage of firms (Damijan et al., 2008) and economies as a whole.

While much is known about the importance of innovation for economic growth and prosperity in other countries, little is known in Cameroon about the innovative activities of firms as Cameroon strives to emerge by 2035 and has set out to enhance her competitive advantage by improving the national system of innovation. In this respect, three actors are principally concerned with the task, namely the firms, universities and the government. Comparing with other science and technologies, indicators in developed world showed that Cameroon needs to do more both at the macroeconomic and microeconomic or firm level. Indeed, according to OECD (2016) the Research and Development (R\&D) expenditure in OECD is $2.4 \%$ of GDP. In these economies, the firms performed better by engaging in $70 \%$ of R\&D. In USA and Japan, each spend more than 3\% of their Gross Domestic Product (GDP) in R\&D. As concerns the Cameroon economy, expenditure on R\&D was estimated at only $1.25 \%$ of her GDP, while the firms' share of R\&D was approximated at only $0.23 \%$ in 2010 . The main aim of the actors in this field is to modernize and innovate. In this context, a free trade agreement has been enacted between Cameroon and the European Union aimed at starting an ambitious programme which will modernize firms called "mise à niveau". The institutional environment concerned with this agreement tries to incite firms to innovate and also to create innovating firms by offering a wide range of incentives and a programme of entrepreneurship which strengthen the relationship between universities and industries.

Mohnen et al. (2006) showed that in developed countries the Community Innovation Surveys (CIS) were used to analyse the characteristics of innovating firms that have been progressively introduced in many countries. Tunisia conducted her CIS in 2005 and used the analysis of the data generated from the survey to better understand the behaviour of innovation of firms in different sectors of the economy. In Cameroon, CIS data is quasi-absent making it difficult to assess the contribution of different types of innovations on export performance.

Meanwhile, it has been shown that manufacturing firms play an important role in modern economies and that the output from firms represents a potential engine for growth in Less Developed Countries (Tybout, 2000). Productivity enhancement therefore, remains crucial to the drive for rapid industrialization and economic growth in developing economies (Ndulu and O'Connell, 1999). Public policy debates hold that lack of growth-oriented firms is a main obstacle to economic growth; and that new firms and entrepreneurs greatly reduce the unemployment rate by creating employment opportunities. Unfortunately, little is known about the growth processes of individual firms and the performance of firms in many Sub-Saharan African economies. It is in this context that manufacturing firms in general, the efficiency and export performance of such firms in particular, remain topical in developing countries like Cameroon.

Though, measurement and determinants of efficiency and export performance of manufacturing firms have drawn a lot of research attention in Sub-Saharan Africa (Faruq and Yi, 2010), much of it has focused on measuring the efficiency of the manufacturing sector. Most recent research on Cameroon has focused on differences in efficiency, rather than measuring it. Efficiency and productivity provide criteria for measuring and improving the manufacturing sector in Cameroon. Research on manufacturing firms' efficiency and export performance in Cameroon is still growing and far from being complete. Much still has to be known about factors that cause differences in efficiency and export performance among manufacturing firms.

Cameroon has been increasing concern on the state of productivity in its manufacturing sector, given that the sector is of great importance to the economy. It employs around 9.2 percent of the total labour force, supplies its output both in domestic and foreign markets, generates foreign exchange receipts (up to 35 per cent of export receipts) and contributes up to 17.5 percent to the Gross Domestic Product (GDP) at current prices. Moreover, it has the potential to induce most of the linkage effects on the other sectors. According to statistics from the National Institute of Statistics for Cameroon in 2009, the performance of this sector has been declining in recent years, largely because of a decline in the number of firms as well as a continuous decline in output. For instance, the manufactured output declined by 0.44 per cent on average between 1995/96 and 2005/06 (World Trade Report, 2007). Njikam (2008) hold that the main causes of the fall in manufactured output include the decline in manufactured commodity prices, appreciation of the Communauté Financière de l'Afrique (CFA) Franc relative to the US dollar, a cumbersome administrative machinery, poor management of public enterprises, poor macroeconomic policies, and cutbacks in government subsidies to firms. In this direction, Faruq and Yi (2010) suggest that efforts to improve efficiency and export performance should focus on the best use of inputs.

However, Cameroon's manufacturing sector suffers from inadequate resources to produce the required quality output 
acceptable in foreign markets. Persistent decline in the output coupled with a significant disinvestment in firms, the government of Cameroon undertook a number of measures to create a sectoral environment likely to boost firms' productivity, reduce production costs and increase incomes of those in the sector. Tybout (2000) holds that the performance of the manufacturing sector is on the whole important for sustained growth and poverty reduction. However, the manufacturing sector in Cameroon ranks third after agriculture and the oil sectors in terms of contribution to GDP. Consequently, there is need for a rapid output growth in this sector. Should this rapid growth be pursued through expansion of the sector or on protecting existing firms or encourage the firms in the sector to be innovative?

Knowledge of returns to innovation activities of firms in foreign markets is important for an economy that wants to emerge by 2035 like Cameroon. Unfortunately, inadequate human capital and technology makes innovation costly. The export market offers the opportunity for these economies to benefit from economies of scale, technology transfer and new learning opportunities. It is therefore important to innovate so as to effectively penetrate the foreign markets. This study aims at identifying the types of innovations used by manufacturing firms in Cameroon and determining the effect of the different innovation types on manufacturing firms' export performance in Cameroon.

The rest of the paper is structured as follows; Section two reviews both theoretical and empirical literature on innovations and export performance while section three discusses the estimation framework and the data used in the analyses. The empirical evidence of the effects of innovation types on export performance of Cameroonian manufacturing firms is reported in section four. Section five concludes the paper with some policy implications.

\section{Literature Review}

Generally, innovation is understood to be the action or process of innovating that is introducing a new method, idea or product. Given that the global market place is characterised by intense social, economic and technological changes, innovation tends to address the organisation's ability to respond and adapt to external and/or internal change (Burns and Stalker, 1961). Kanter (1988) considers innovation as an organisation's ability to encourage innovation in both process and product produced, regardless of an instantaneous need for change. In Hamel and Prahalad (1994), the concepts of strategy and innovation are introduced. The concept of innovation stressed the increasing requirement of modern organizations to proactively address the challenges of the future by undertaking radical innovations that will transform both their surroundings and the marketplace.

However, according to Schumpeter (1936) innovation encompasses the entire process, which starts with the development of an idea and continues through all the stages to become a marketable product that can change the economy. This concept is clearer if innovation is defined in terms of adopting structures new to an institution and relevant environment (knight, 1967). Thus, the use of the word 'adoption' considers innovation beyond the concept of a new idea. This led to Johannessen et al. (2001) to pose the following questions: what is new, how new, and new to whom? This led to the identification of six types of innovation activities namely: new products, new services, new methods of production, opening new markets, new sources of supply and new ways of organizing. Innovation has also been considered as an organization's capability to produce new value scheme for investors which forces firms to design fresh worth in the form of new products, new processes or novel ways of doing business (Dervitsiotis, 2010).

Other definitions take innovation as the capacity to introduce new procedures, products or ideas in the organization (Aranda et al., 2001) while Bigliardi \& Dormio (2009) described it as the art of generating, developing and adapting to new ideas or ways of doing things in the firms. Aranda et al. (2001) considered innovation to be successful if it is based on either the effect of changes in the product or process that has accumulated over time or on innovative mixture of techniques, ideas or methods that have existed. In this direction, Mole \& Worall (2001) noted that innovation can be radical or incremental. It is radical when a new technology, process or product is introduced that meets the needs but is not yet accepted. On the other hand, innovation is incremental if it is aimed at improving upon what is in existence. Accordingly, the level of innovation that a firm adopts may depend on the capability to acquire new products, production process or to modify the products that exist and penetrate new markets or segments in established markets (Salavou, 2002).

From the foregoing discussion it is obvious that there are many types of innovations. According to OECD (2005), four types of innovation exist viz product innovation, process innovation, marketing innovation and organizational innovation. Product innovation introduces new products and services or significantly improves on those that exist (Polder et al., 2010). Thus, this requires a new product or that the feature, intended use, software, or components and material of the product be significantly improved. Process innovation improves the production and logistic techniques or brings improvement in the activities that support aspects such as purchases, account keeping, repairs and computation (Polder et al., 2010). It should be noted that the innovative aspects in terms of the product and process are highly linked to the idea of development in technology. Marketing innovation relates to the implementation of new marketing methods. This may include changes in the ways the product is packaged, designed, placed, promoted and priced (OECD, 2005). The main aim of marketing innovation is to improve upon the quantity sold, gain more 
proportion of the markets and penetrate into new markets. Lastly, organizational innovation simply introduces new ways as aspects such as; to do business, make decisions, manage the workplace; and relate with external partners (Polder et al., 2010).

The new methods that accompany innovative activities have a great role to play in influencing organizational performance in terms of behaviour, productivity and sales. At the level of firms, Teece (1996) argued that firms carrying out innovation are encouraged to penetrate the foreign markets, as this result to higher profits or returns from the investments. Previous empirical studies have revealed that the effect of innovation on performance of export is statistically significant and positive. In a study by Hirch and Bijaoui (1985) using a case study of 111 Israeli firms to examine the effect of innovation on export performance, they found out that firms carrying out innovative activities had a higher probability to engage in export activities. Their results showed that a key determinant of export performance is the innovative activities carried out by firms. The researchers advanced that firms involved in innovation had higher growth in terms of exports than firms not involved in innovative activities. In a similar study carried out by Smith et al. (2002) on the role played by innovation, they found out that firms engaged in quickly surmount obstacles that come with international trade. Their results showed that innovations in product and process have a positive effect on the level of export in the manufacturing firms in Turkey.

Other authors such as Wright, Palma and Perkins (2004) and Ussahawanitchakit (2007) noted that innovation can play both a positive and negative role in influencing the performance of exports from manufacturing firms. In this light, Ussahawanitchakit (2007) put forward that a firm can successfully engage in the international business markets only by exploiting the innovative capabilities and learning how to succeed in an environment that is competitive. In this way the firm can sustain the stiff competition and achieve growth in the level of exports. Minguel and Elena (2009) argued that innovative activities remain a necessary tool for firms that operate in the international market especially given that the international environment is very competitive. In the same light, Xayhone and Yoshi (2009) asserted that with innovation firms have the capacities to increase and support a strong export competitiveness which can eventually result to a sustainable export performance. However, the positive effects of innovative activities may be constrained by financial difficulties thus the long run benefits may be eroded as argued by Freel (2006).

Empirical studies have shown evidence that innovation plays a key role in determining exporters and non-exporters. A study using a panel data set of Spanish firms by Barrios, Görg and Strobl (2003) found that Research and Development (R\&D) expenditure by the firms has a positive influence on the firm's probability and intensity to export. In another study applying instrumental variable approach with respect to innovation, Lachenmaier and WÖßmann (2006) found that the volume of exports of 982 German firms was positively affected by their innovation expenditures. A similar result was obtained by Tomiura (2007) for a large sample of Japanese firms. The results from the study showed that R\&D intensity was a significant determinant of the probability to export by manufacturing firms.

A study of Spanish firms by Caldera (2010) found out that a majority of the firms that were more productive and considered as innovators were more likely to become exporters, as a result of a reduction in the marginal cost associated with innovation. In a similar study, D'Angelo (2012) obtained results showing that the export intensity was positively influenced by the share of research and development that the firms were employing, the collaboration with universities for research and development activities; the introduction of product and process innovations and the turnover from innovative activities. The above results are confirmed by Frazzoni et al. (2011), who in their study found out that lending relationship and innovative capacity were the main determinants of both the probability to export and intensity of export when studying a sample of 7560 manufacturing firms in Italy. Their results showed that when product innovation was introduced by firms, the firm's exporting activity increased, while the introduction of process innovations did not have any statistical significant effect.

Some other studies have focus attention on the competitive advantage brought by innovation. A study conducted by Abou-Moghli, Al Abdallah and Al Muala (2012) focusing on the competitive advantage in the Jordanian banking sector showed that innovation has a direct positive impact on competitive advantage through various dimensions such as time, quality, cost, and flexibility. The results showed further that introducing products and process innovations allow the banks to customize their products and services based directly on customers' requirements and also give room to banks to offer product and service in response to competition. In a similar study, Noorani (2014) studied the effect of innovation on competitive advantage using a sample of Online Business to Business Matching companies. The results obtained showed that the differences found in organizational performance in the context of Online Business can be partially explained by Information Technology, Human Resource Management, Research \& Development and strategic alliances practices and policies.

Most of the studies related to innovation types and export performance of manufacturing firms reviewed above are mainly based in developed countries and focus only on either product innovation or process innovation or both. There is a serious lack of study focused on the effect of non-technological innovation on export performance. All these studies 
emphasised on the capacity of product and/or process innovation to lead to export performance of manufacturing firms. There is a quasi-absence of such studies in less developed countries due to unavailability of data related to innovations. Thus, the relevance of the present study to provide recent data on four types of innovation using manufacturing firms in Cameroon. Moreover, the study used a single model to incorporate all these types of innovations as well as firm's specific factors and business environment factors in order to determine the effect of export intensity and export propensity of Cameroonian manufacturing firms using Logit and Tobit models.

\section{Empirical model and data description}

The export performance of the firm was captured by two elements - the decision to export and the volume exported. The export decision or propensity equation is expressed as:

$$
\begin{aligned}
\text { EXP }_{i}= & \alpha+\alpha_{1} \text { product }_{i}+\alpha_{2} \text { process }_{i}+\alpha_{3} \text { market }_{i}+\alpha_{4} \text { org }_{i} \\
& +\alpha_{5} \text { firmsize }_{i}+\alpha_{6} \text { firmage }_{i}+\alpha_{7} \text { capital }_{i}+\alpha_{8} \text { train }_{i} \\
& +\alpha_{9} \cos \text { tfinance }_{i}+\alpha_{10} \text { corruption }_{i}+\alpha_{11} \text { macroperception }_{i}+\varepsilon_{i}
\end{aligned}
$$

Where $\mathrm{EXP}_{\mathrm{i}}$ is defined as;

$$
E X P_{i}=\left\{\begin{array}{l}
1 \text { if firm } i \text { export } \\
0 \text { otherwise }
\end{array}\right.
$$

The export volume equation is stated as:

$$
\begin{aligned}
\text { EXVol }_{i}= & \alpha+\alpha_{1} \text { product }_{i}+\alpha_{2} \text { process }_{i}+\alpha_{3} \text { market }_{i}+\alpha_{4} \text { org }_{i} \\
& +\alpha_{5} \text { firmsize }_{i}+\alpha_{6} \text { firmage }_{i}+\alpha_{7} \text { capital }_{i}+\alpha_{8} \text { train }_{i} \\
& +\alpha_{9} \cos \text { tfinance }_{i}+\alpha_{10} \text { corruption }_{i}+\alpha_{11} \text { macroperception }_{i}+\varepsilon_{i}
\end{aligned}
$$

Equation (1) estimates the probability to export using a logit estimation technique while the volume of export or the intensity to export, equation (2) is estimated through the Tobit estimation procedure. The Tobit model is appropriate for censored data and incorporates the decision to export and the quantity of exports relative to sales in the same model. In the two equations, the independent variables were included to reflect innovation variables, firm specific heterogeneity, and environmental factors. The innovation specific variables which affect firm's productivity and ability to compete on the international markets are product innovation ( product), process innovation (process), market innovation (market) and organization innovation ( org ). The firm specific factors are firm size ( firmsize), firm age ( firmage), capital intensity (capital), and training (train). The business environmental factors included are cost of finance (costfinance), corruption (corruption) and macroeconomic perception (macroperception). A comprehensive definition of the variables and their expected signs are presented in Table 1 below.

Table 1. Definition of variables

\begin{tabular}{lll}
\hline Variables & \multicolumn{1}{c}{ Measurement/definition } & Expected sign \\
\hline Export propensity & 1 if firm exports and zero otherwise & \\
Export intensity & Proportion of firms output exported & + \\
Process innovation & 1 if firm has carried out process innovation and zero otherwise & + \\
Organisation innovation & $\begin{array}{l}1 \text { if firm has carried out organizational innovation and zero } \\
\text { otherwise }\end{array}$ & + \\
Market innovation & 1 if firm has carried out market innovation and zero otherwise & + \\
Product innovation & $\begin{array}{l}1 \text { if firm has carried out product innovation and zero otherwise } \\
\text { Size }\end{array}$ & $\begin{array}{l}\text { Stock of asset of firm measured as the difference between date of } \\
\text { Age }\end{array}$ \\
establishment of firm and date of collection of data & + \\
Corruption & Perception of corruption by the firm, ranges from 1 to 9 & + \\
\hline
\end{tabular}




\begin{tabular}{lll}
\hline Staff Training & Cost of staff training & \\
$\begin{array}{l}\text { Cost of finance } \\
\begin{array}{l}\text { Macroeconomic } \\
\text { perception }\end{array}\end{array}$ & $\begin{array}{l}\text { Perception on the cost of obtaining finance from financial } \\
\text { institutions, ranges from } 1 \text { to } 9\end{array}$ \\
$\begin{array}{l}\text { Capital intensity } \\
\text { Perception on the stability of the macro economy, ranges from } 1 \text { to } 9\end{array}$ & + \\
\hline
\end{tabular}

Source: The author

The table gives the definition of each of the variables used in the study and their expected signs.

The data used for this study are secondary collected on manufacturing firms in Cameroon between 2011 and 2013 . The data are based on an inquiry led by the International Development Research Centre (IDRC) on the performance of firms in French Sub Saharan Africa with Cameroon as a case study. The survey was conducted on a sample of 937 firms in both the formal and informal sectors including firms at all stages of production. However, the analyses in this study were based on 183 manufacturing firms. From the data it was found that most of the firms have introduced a combination of innovative activities simultaneously.

The data showed that in total 57 firms introduced product innovation, 88 with process innovation, 58 with market innovation and 84 with organizational innovation. For organizational innovation, 56 firms had introduced new ways of functioning, 84 new methods of external relation with other firms or organizations and 39 new organizational methods of work and taking accounting decisions. As concerns marketing innovation, the data showed that 36 firms had introduced new methods of promoting their products, 70 redesigned the presentation of their products, while 51 of the firms had new sales distribution points and 75 introduced new strategies for stratification of products.

In terms of sources of innovation, between 2011 and 2013, 118 firms used information from their own sources for their innovative activities. About 34.43 percent of manufacturing firms had integrated the information coming from competitors in the production of the same product and expertise concerning the manufacture of the product. Only 6 percent of manufacturing firms used information from institutions such as Universities, Research and Development Organizations. 11 manufacturing firms indicated that they used sources other than those mentioned above in their activities of innovation.

As concerns factors hindering innovation, most of the firms $(61.2 \%)$ indicated lack of internal financial resources as a major hindrance to their ability to carry activities to foster product, process, marketing and organizational innovation. Furthermore, Only 65 (35.5\%) of the manufacturing firms indicated lack of external financial resources as a hindrance. High cost of innovation, difficulties to find partners for cooperation, lack of information on technological changes, lack of qualified personnel were among the many factors identified as hindering the process of innovation by manufacturing firms in Cameroon.

\section{Empirical results on the effect of innovation on export performance}

The regression results are presented in Table 2. The results for the export intensity estimated using the Tobit estimation technique are presented in column two while the propensity or probability to export results estimated using the Logit technique are found in column three.

The Tobit results indicate that firms undertaking organizational innovation enjoy 0.19 units more in terms of the proportion of goods exported. The coefficient for market innovation is also positive indicating that firms that undertake innovative activities in the market channel perform better. The results precisely show that a firm that undertakes market innovation exports 0.35 unit more than firms that do not innovate in the market. Both innovative activities are statistically significant in influencing export performance and consistent with the results of Caldera (2010).

Table 2. Regression results for the effect of innovation types on export performance

\begin{tabular}{lcc}
\hline VARIABLES & TOBIT & LOGIT \\
& Export intensity & Propensity to export \\
\hline & Coefficient & Coefficient \\
& $(t$-statistics $)$ & $($ t-statistics $)$ \\
Process innovation & 0.04301 & 0.1218 \\
Organisation innovation & $(0.83)^{* *}$ & $(0.26)^{* * *}$ \\
Market innovation & $0.1914^{* *}$ & $(2.6)^{*}$ \\
& $(2.51)^{* *}$ & $1.1490^{*}$ \\
\hline
\end{tabular}




\begin{tabular}{|c|c|c|}
\hline Product innovation & $\begin{array}{c}0.2223^{*} \\
(1.75)\end{array}$ & $\begin{array}{l}0.4644 \\
(0.96)\end{array}$ \\
\hline Size & $\begin{array}{c}0.1389^{*} \\
(1.93)\end{array}$ & $\begin{array}{c}0.2186^{*} \\
(1.68)\end{array}$ \\
\hline Age & $\begin{array}{c}0.0072^{* * * *} \\
(3.20)\end{array}$ & $\begin{array}{c}0.0187^{*} \\
(1.68)\end{array}$ \\
\hline Corruption & $\begin{array}{c}-0.0011 \\
(-0.04)\end{array}$ & $\begin{array}{c}-0.3410^{* * *} \\
(-2.11)\end{array}$ \\
\hline Staff Training & $\begin{array}{c}0.0389^{*} \\
(1.73)\end{array}$ & $\begin{array}{c}0.2887^{*} \\
(1.76)\end{array}$ \\
\hline Cost of finance & $\begin{array}{c}-0.0038 \\
(-0.27)\end{array}$ & $\begin{array}{c}-0.1316 \\
(-0.94)\end{array}$ \\
\hline $\begin{array}{l}\text { Macroeconomic } \\
\text { perception }\end{array}$ & $\begin{array}{c}0.0826^{* *} \\
(2.04)\end{array}$ & $\begin{array}{c}0.3234^{* * *} \\
(2.03)\end{array}$ \\
\hline Capital intensity & $\begin{array}{l}0.0046 \\
(0.64)\end{array}$ & $\begin{array}{l}0.1196 \\
(1.17)\end{array}$ \\
\hline Constant & $\begin{array}{c}-0.6974^{* * *} \\
(-2.10)\end{array}$ & $\begin{array}{l}-0.4249 \\
(-0.53)\end{array}$ \\
\hline Sigma & 0.0939 & \\
\hline Pseudo R-square & 1.5405 & 0.2310 \\
\hline LR chi2(11) & 63.61 & 41.00 \\
\hline Prob > chi 2 & 0.0000 & 0.0000 \\
\hline
\end{tabular}

The coefficient of product innovation is positive and also statistically significant at $10 \%$ level of significance. This implies that firms engaged in product innovation export 0.22 units more than firms that do not innovate in terms of the product. The findings are in line with those of Roper and Love (2002), whose results showed that product innovations have a positive effect on the likelihood to export and on the intensity of exports of manufacturing firms in the UK and Germany. The results are also consistent with the findings of Basile (2001) and Wakelin (1998). The results, however, contradict those obtained by Damijan et al. (2008) whose results showed that product innovation is likely to cause employment growth, but not significant productivity growth. Overall, the results are consistent with the existing literature indicating that product innovation is a major determinant of the proportion of exports.

The results further show that firms that undertake process innovation enjoy 0.043 unit of export intensity more. However, the difference is not statistically significant. The result is consistent with those of Frazzoni et al. (2011), implying that process innovations do not significantly affect the export intensity. However, the positive effect is consistent with the findings of Özçelik and Taymaz (2004) and Basile (2001) who all found that process innovation improves on the export performance.

The result also indicates that an increase in the size of the firm will lead to an increase in the export intensity. More precisely, a unit increase in size of the firm leads to an increase in export intensity by 0.14 units. The result is consistent with those of Wagner (2008) and Kaynak and Kuan (1993) who found that an increase in size of the firm results to a sequential and gradual increase in terms of the marketing attitudes of exports and export size. However, the findings are contrary to those of Cavusgil and Kirpalani (1993) who found a negative relationship between firm's size and export performance.

The coefficient of age of the firm is positive indicating that older firms export more. The results show that an increase in the firm's age by one year will result to an increase in the export intensity by 0.007 units. The findings are consistent with those of Welch and Weidersheim-Paul (1980). The positive effect of age on export intensity can be explained by the fact that older firms are usually considered to be more efficient than younger ones since the owners, managers and employees have gained experience from past operations. Furthermore, older firms have cumulative experience, business networks and reputation. The result is however in contrast to the ideas of Niringiye et al. (2010), who pointed out that young firms are more proactive, flexible, and aggressive compared to old firms. As a result they are more willing to adopt modern technology, while older firms are stuck with outdated physical capital.

Other results showed that corruption and cost of finance both have a negative but statistically insignificant effect on the intensity to export, while staff training and macroeconomic perception have a positive and statistically significant effect on the intensity to export. Finally, the coefficient of capital intensity is positive indicating that an increase in the capital usage will result to an increase in the intensity to export. However, this positive effect is statistically insignificant. 
The logistic results for the probability to export are quite consistent in terms of sign with the Tobit results. The results show that the likelihood to export will increase when innovative activities are carried out by the manufacturing firms. The results show that when a firm carries out process innovation the likelihood to export will increase by 0.12 , while involving in market innovations increases the likelihood to export by 1.15. Product innovation increases the probability to export by 0.46 while organizational innovation improves the probability to export by 1.601 . The results are consistent with those of Damijan et al. (2008), and Girma et al. (2007). Other results from the logit estimation show that the size of the firm, training of employees, capital intensity, macroeconomic stability and age of the firm all have positive coefficients implying that the likelihood of the firm to export increases with the increase in the magnitude of these variables. However, corruption and the cost of finance have a negative effect on the likelihood to export.

\section{Conclusion and Policy implications}

Previous research has examined the effects of innovation types on export performance of manufacturing firms mainly based in developed countries and focus only on either product innovation or process innovation or both. There is a serious lack of study focused on the effect of non-technological innovation on export performance. In addition, there is a quasi-absence of such studies in developing countries striving to emerge and become competitive in the global market. The relevance of the present study is based on the fact that it considers the effect of innovation types on export performance of manufacturing firms in a developing country, notably Cameroon. In addition, the study explores simultaneously the effect of technological and non-technological innovations on export performance using a single model. Thus, this research provides a unique opportunity for the understanding of the various forms of innovative activities carried out by firms and the effect of such on the propensity and intensity to export by manufacturing firms in Cameroon. The results can therefore support and boast the government's effort in promoting innovative activities in both the non-manufacturing and manufacturing sectors in Cameroon.

This paper aimed at investigating the effect of innovation types on the performance of manufacturing firms in Cameroon. Specifically, export performance is captured in terms of export propensity and export intensity. This was achieved by using secondary data collected on manufacturing firms in Cameroon between 2011 and 2013 by the International Development Research Centre (IDRC) on the performance of firms in French Sub Saharan Africa using Cameroon as case study. The effects of innovation types on export intensity were examined using the Tobit estimation technique while the effect of innovation on the propensity to export was conducted using a logit estimation technique.

The results showed that the manufacturing firms have carried out more than one type of innovation activities. Specifically by innovation types; 57 firms had introduced product innovation, while 88, 58 and 84 firms have introduced process innovation, market innovation and organizational innovation, respectively. For organizational innovation, 56 firms had introduced new ways of functioning, while 84 had new methods of external relation with other firms or organizations and 39 had developed new organizational methods of work and taking accounting decisions. 36 firms had introduced new methods of promoting their products, 70 firms had redesigned the presentation of their products, while 51 of the firms had new sales distribution points and 75 had introduced new strategies for stratification of products.

Empirically, the results showed that globally there is a positive effect of innovation activities on export propensity and export intensity of manufacturing firms in Cameroon. However, disaggregating by types of innovation, only non-technological innovations significantly account for both the variations in export propensity and export intensity of manufacturing firms in Cameroon. The process innovation had a positive and statistically insignificant effect on both measures of export performance, while product innovation had a positive statistically significant effect on export intensity but not on the likelihood or propensity to export. Other results showed that perception for macroeconomic stability, staff training, age of firm and capital intensity had a positive influence on export performance while perception of corruption discouraged both the propensity and intensity to export.

From the results obtained it is therefore evident that for manufacturing firms to improve on their performance they have to continue to develop new ways of doing things among which include new marketing strategies involving significant changes in product design or packaging, product placement, product promotion and pricing. Firms should also take into consideration the needs of customers, opening up new markets and implementing new organizational methods in the firm's business practices, workplace and external relations. Firms are also required to significantly improve the technical specifications of their products, components and materials.

On her part, the government of Cameroon should focus policies towards encouraging and fostering innovation by assisting firms to identify and develop their human resources, improve security, encourage the use of new technologies and promote Research and Development. Government should also continue to promote policies aimed at eradicating corruption that still remains a perennial problem in the country. Policies should also be put in place to boast economic stability and growth. Finally, there is need to continuously reduce cost of financing and improving the capacities of manufacturing firms to fully engage in export activity, regardless of the industry. 


\section{References}

Abou-Moghli, A., Al Abdallah G. M., \& Al Muala, A. (2012). Impact of Innovation on Realizing Competitive Advantage in Banking Sector in Jordan, American Academic \& Scholarly Research Journal, 4(5). http://naturalspublishing.com/files/published/up889x83c79jg4.pdf

Aghion, P., \& Howitt, P. (1992). A Model of Growth Through Creative Destruction. Econometrica, 60(2), 323-351.

Alhakimi, W., \& Baharun, R. (2009). A Synthesis Model of Market Orientation Constructs Toward Building Customer Value: A Theoretical Perspective. African Journal of Marketing Management, 1(2), 43-49.

Aranda, A., Daniel, Minguela, B., \& Rodriguez, A. (2001). Innovation and Firm Size. An Empirical Study for Spanish Engineering Consulting Companies. European Journal of Innovation Management, 4(3), 133-141. http://dx.doi.org/10.1108/EUM0000000005671

Barrios, S., Görg, H., \& Strobl, E. (2003). Explaining Firms’ Export Behaviour: R\&D, Spillovers and the Destination Market. Oxford Bulletin of Economics and Statistics, 65(4), 475-496. http://ssrn.com/abstract=423648

Basile, R. (2001). Export Behaviour of Italian manufacturing firms Over the Nineties. The role of Innovation. Research Policy, 30, 1185-1201.

Bigliardi, B., \& Dormio, A. I. (2009). An Empirical Investigation of Innovation Determinants in Food Machinery Enterprises. European Journal of Innovation Management, 12(2), 223-242.

Burns, T., \& Stalker, G. M. (1961). The Management of Innovation. London Tavistock.

Caldera, A. (2010). Innovation and Exporting: Evidence from Spanish Manufacturing Firms. Review of World Economics, 146, 657-689. http://www.ssoar.info/ssoar/handle/document/26281

Cavusgil, Tamer S. \& Kirpalani, Maneck V. H. (1993). Introducing Products into Export Markets: Success Factors. Journal of Business Research, 27, 1-15.

D’Angelo, A. (2012). Innovation and export performance: A Study of Italian High-Tech SMEs. Journal of Management and Governance, 1-31.

Damijan, P. J., Kostevc, C., \& Rojec, M. (2008). Innovation and Firms 'Productivity Growth in Slovenia: Sensitivity of Results to Sectoral Heterogeneity and to Estimation Method. Licos Discussion Paper, 203. http://dx.doi.org/10.2139/ssrn.1131155

Dervitsiotis, K. N. (2010). A Framework for the Assessment of an Organization's Innovation Excellence. Total Quality Management, 21(9), 903-918.

Faruq, H. A., \& Yi, D. T. (2010). The Determinants of Technical Efficiency of Manufacturing Firms in Ghana. Global Economy Journal, 10(3), 1524-5861

Frazzoni, S., Mancusi, M. L., Rotondi, Z., Sobrero, M., \& Vezzulli, A. (2011). Relationship with Banks and Access to Credit for Innovation and Internalization of SMEs, in Bracchi, G., Masciandaro, D., Bancaria Editrice, Milano, 93-114,

Freel, M. (2006). Patterns of Technological Innovation in Knowledge-Intensive Business Services. Industry and Innovation, 13(3), 335-58. http://dx.doi.org/10.1080/13662710600859157

Girma, S., Kneller, R., \& Pisu, M. (2007). Do Exporters Have Anything to Learn From Foreign Multinationals. European Economic Review, 51(4), 981-998.

Griffith, R. E., Huergo, M. J., \& Peters, B. (2006). Innovation and Productivity Across Four European Countries. Oxford of Economic Policy, 22, 483-498.

Hamel, G., \& Prahalad, C. K. (1994). Competing for the Future. Harvard Business Review, 122 - 128.

Hirch, S., \& Bijaoui, I. (1985). R \& D Intensity and Export Performance: A Micro View, Weltwirtschaftliches Archiv, $121,238-251$.

Hoq, M., \& Norbani, H. (2009). Innovativeness: Its Antecedents and Impact on SME Business Performance. International Journal of Business and Management, 4(11).

Jasmine, E., \& Williams, M. (2005). Export Marketing Information Gathering and Processing in Small and Medium-Sized Enterprises. Marketing Intelligence \& Planning, 24(5), 477-492.

Johannessen, J. A., Olsen, B., \& Lumpkin, G. T. (2001). Innovation as Newness: What is New, How new, and New to Whom? European Journal of Innovation Management, 4(1), 31.

Kanter, R. M. (1988) When a Thousand Flowers Bloom: Structural, Collective and Social Conditions for Innovation in 
Organisation. Research in Organisational Behaviour, 10.

Kaynak, E., \& Kuan, W. K. (1993). Environment, Strategy, Structure, and Performance in the Context of Export Activity: An Empirical Study of Taiwanese Manufacturing Firms. Journal of Business Research, 27, 33-49.

Knight, K. E. (1967). A Descriptive Model of the Intra-Firm Innovation Process. The Journal of Business, 40(4), 478-496.

Lachenmaier, S., \& WÖßmann L. (2006) Does Innovation Cause Exports? Evidence from Exogenous Innovation Impulses and Obstacles Using German Micro Data. Oxford Economic Papers, 58(2), 317-350.

Minguel, H., \& Elena. D. (2009). Product Innovation in Small Manufacturers, Market Orientation and the Industry ${ }^{\text {ee }}$ Five Competitive Forces Empirical Evidence from Spain. European Journal of Innovation Management, 12(4).

Mohnen, P., Mairesse, J., \& Dagenais, M. (2006), Innovativity: A Comparison Across Seven European countries, NBER Working Paper, 15(4-5), 391-413. http://www.nber.org/papers/w12280

Mole, K., \& Worall, L. (2001). Innovation, Business Performance and Regional Competitiveness in the West Midlands. European Business Review, 13(6). http://dx.doi.org/10.1108/EUM0000000006198

Narver, J. C., \& Slater, S. F. (1990). The Effect of Market Orientation on Business Profitability. Journal of Marketing, 20-35. http://www.jstor.org/stable/1251757

Ndulu, B. J., \& O’Connell, S. A. (1999). Governance and Growth in Sub-Saharan African. Journal of Economic Perspectives, 13(3), 41-66.

Niringiye, A., Luvanda, E., \& Shitundu, J. (2010). The relationship Between Firm Size and Technical Efficiency in East Africa Manufacturing Firms. Journal of Sustainable development in Africa, 12(4), 226-236

Njikam, O. (2008). The Effects of Trade Reform on Cameroon's Manufacturing Industries. In A. J. Amin (Ed), Developing a Sustainable Economy in Cameroon, 125-154. Dakar.

Noorani, I. (2014). Service Innovation and Competitive Advantage. European Journal of Business and Innovation Research, 2(1), 12-38

OECD (2005). Handbook on Economic Globalisation Indicators. OECD, Paris.

OECD (2016). Research and Development Statistics (RDS), www.oecd.org/sti/rds

Özçelik, E., \& Taymaz, E. (2004). Does Innovativeness Matter for International Competitiveness in Developing Countries. Research Policy, 33, 409 - 424. http://dx.doi.org/10.1016/j.respol.2003.09.011

Polder, M., Leeuwen, G.V., Mohnen, P., \& Raymond, W. (2010). Product, Process and Organizational Innovation: Drivers, Complementarity and Productivity Effects. UNU-MERIT, Maastricht Economic and Social Research and Training Centre on Innovation and Technology. http://dx.doi.org/10.2139/ssrn.1626805

Riasi, A. (2015). Competitive Advantages of Shadow Building Banking Industry: An Analysis Using Porter Diamond Model. Business Management and Strategy, 6(2). http://dx.doi.org/10.5296/bms.v6i2.8334

Rogers, E. M. (2003), Diffusion of Innovations, Fourth Edition, The Free Press, New York.

Roper, S., \& Love, J. H. (2002). Innovation and Export Performance: Evidence from the UK and German Manufacturing Plants. Research Policy, 31, 1087-1102. http://dx.doi.org/10.1016/S0048-7333(01)00175-5

Salavou, H. (2002). Profitability in Profit Oriented SMEs: Does Product Innovation Matter?. European Journal of Management Innovation, 5(3).

Schumpeter, J. (1942). Capitalism, Socialism and Democracy. Allen and Unwin, London.

Schumpeter, J., A. (1936). The Theory of Economic Development, Second Edition. Cambridge: Harvard University press.

Smith, V., Erik, S. M., \& Mogens, D. H. (2002) Do R\&D Investments Affect Export Performance? University of Copenhagen, Institute of Economics, Centre for Industrial Studies, Discussion Paper.

Sousa, M. C., \& Alserhan, A. B. (2002). An Investigation into the Antecedents of the Export Performance, Competitive Paper, University College Dublin

Teece, D. J. (1996) Firm Organization, Industrial Structure and Technological Innovation. Journal of Economic Behavior and Organization, 31, 192 - 224. http://dx.doi.org/10.1016/S0167-2681(96)00895-5

Tesfom, G., \& Litz, C. (2006). A Classification Of Export Marketing Problems of Small and Medium Sized Manufacturing Firms In Developing Countries. International Journal of Emerging Markets, 1(3), 262-28. http://dx.doi.org/10.1108/17468800610674480 
Tomiura, E. (2007). Foreign Outsourcing, Exporting, and FDI: A Productivity Comparison at The Firm Level, Journal of International Economics, 72, 113-127. http://dx.doi.org/10.1016/j.jinteco.2006.11.003

Tybout, J. R. (2000). Manufacturing Firms in Developing Countries: How Well do they do, and Why? Journal of Economic Literature, 38, 11-44.

Ussahawanitchakit, P. (2007). Innovative Capabilities and Export Performance: An Empirical Study of Textile Business in Thailand, International Journal of Business Strategy, 7(1).

Wagner, J. (2008). Export and Firm Characteristics: First Evidence from Fractional Probit Panel Estimates, University of Luneburg Working Paper Series in Economics, 97.

Wakelin, K. (1998). Innovation and Export Behavior at the Firm Level. Research Policy, 26, 829-841. doi:10.1016/S0048-7333(97)00051-6

Welch, Lawrence S., \& Wiedersheim-Paul, Finn (1980), Initial Exports - A Marketing Failure?, Journal of Management Studies, 17(2), 331-344.

World Trade Report (2007) Six Decades of Multilateral Trade Cooperation: What have we Learnt? World Trade Organisation, Switzerland

Wright, R.E., Palmer, J. C., \& Perkins, D. (2004). Types of product innovations and small business performance in hostile and benign environments. Journal of Small Business Strategy, 15(2), 33-44. http://libjournals.mtsu.edu/index.php/jsbs/article/view/33/11

Xayphone, K., \& Yoshi, T. (2009). Innovation, Export Performance and Profitability of Lao Garment Exporters International. Journal of Economics and Management, 3(2), 225 - 236

\section{(cc) $E_{Y}$}

This work is licensed under a Creative Commons Attribution 3.0 License. 